\title{
Evaluasi proses penyusunan instrumen penilaian kognitif
}

\author{
Rahma Putri Jati ${ }^{1^{*},}$ Nani Aprilia ${ }^{2}$ \\ Program Studi Pendidikan Biologi, Fakultas Keguruan dan Ilmu Pendidikan, Universitas Ahmad Dahlan, \\ Jl. Jendral Ahmad Yani (Ringroad Selatan) Tamanan, Banguntapan, Bantul, \\ Daerah Istimewa Yogyakarta 55191 \\ 1 rahmaputri8813@gmail.com*; ${ }^{2}$ nani.aprilia@pbio.uad.ac.id \\ *korespondensi penulis
}

\begin{abstract}
Abstrak
Banyak guru yang belum memperhatikan prosedur dalam menyusun instrumen tes sebagai alat penilaian menjadi latar belakang dalam penelitian ini. Kurangnya sosialisasi dan pelatihan juga menjadi penyebab rendahnya pemahaman guru terhadap prosedur penyusunan tes. Penelitian ini bertujuan untuk mengetahui kesesuaian langkah pengembangan tes yang dilakukan guru dengan prosedur penyusunan instrumen tes serta mengetahui persentase kesesuaian langkah pengembangan tes yang dilakukan guru dengan prosedur penyusunan instrumen tes.

Penelitian ini termasuk dalam penelitian evaluasi. Populasi dalam penelitian ini yaitu seluruh guru mata pelajaran IPA di SMP Negeri Sekecamatan Bantul. Teknik pengambilan sampel menggunakan sampel jenuh sehingga seluruh anggota populasi dijadikan sampel. Teknik pengumpulan data yang digunakan yaitu kuesioner dan wawancara dengan instrumen menggunakan lembar kuesioner dan pedoman wawancara. Teknik analisis data yang digunakan berupa analisis deskriptif kuantitatif.

Hasil penelitian menujukkan bahwa $100 \%$ guru sudah mengikuti sosialisasi maupun pelatihan pembuatan instrumen tes. Namun ketika guru menyusun instrumen tes, guru kurang paham akan langkah dalam penyusunannya. Dari sembilan langkah dalam penyusunan instrumen tes sebanyak $75 \%$ guru hanya mengikuti langkah sampai pada langkah ke dua saja yaitu menulis tes, sebanyak $18,75 \%$ guru hanya melakukan langkah penyusunan spesifikasi tes, menulis tes, dan melaksanakan tes, dan sebanyak 6,25\% guru melakukan langkah penyusunan spesifikasi tes, menulis tes, uji coba tes, perbaikan tes, dan melaksanakan tes.
\end{abstract}

Kata kunci: evaluasi, instrumen, kognitif, penilaian, prosedur, tes

\begin{abstract}
On the procedure in compiling test instruments as assessment tools. The lacks of socialization and training also contributed to the causes of teachers' low understandings of the test compiling procedure. This study aims to know the relevance of test development steps completed by the teachers with the procedures of the test instrument compiling. Besides, it is to know the percentage resulted from the first question.

This study is categorized into an evaluation research. The population included the entire teachers of the natural science subject in State Junior High Schools in Bantul District. The sample was gathered using saturation sampling, thus the whole population participants became the sample. The data were obtained through questionnaire and interview using questionnaire sheet and interview guide. The data were analyzed using quantitative descriptive analysis.
\end{abstract}


The result shows that $100 \%$ of the teachers have attended the socialization and the training of test instrument composition. However, the teachers found the preparation steps for compiling the test instruments to be difficult. Out of nine steps, only two were completed by $75 \%$ of the participants. Those were composing the tests instruments. As much as $18.75 \%$ of them prepared the test specification, composed the test instrument, and implemented it. Meanwhile, 6.25\% prepared the test specification, composed the test instrument, tried out the test, revised the test, and implemented it.

Keywords: assessment, cognitive, evaluation, instrument, procedure, test

\section{PENDAHULUAN}

Suatu pembelajaran memerlukan persiapan yang matang, meliputi komponen-komponen seperti tujuan pembelajaran, proses pembelajaran, dan evaluasi pembelajaran. Komponenkomponen tersebut merupakan suatu kesatuan yang tidak dapat dipisahkan. Hal ini senada dengan pendapat dari Nuriyah (2014) bahwasanya sebelum melakukan kegiatan pembelajaran guru harus menentukan tujuan pembelajaran yang akan dicapai terlebih dahulu dimana tujuan pembelajaran ini diambil dari Kompetensi Inti (KI) dan Kompetensi Dasar (KD) yang kemudian dituangkan ke dalam indikator-indikator. Indikator ini yang akan menentukan arah selama proses pembelajaran. Pada akhir proses pembelajaran ini siswa harus menguasai Kompetensi Dasar (KD) yang telah dipelajarinya. Untuk mengetahui apakah siswa telah menguasai materi atau belum dilakukan dengan evaluasi pembelajaran.

Selama pelaksanaan pembelajaran, untuk mengetahui berhasil tidaknya proses pembelajaran tersebut dapat dilakukan dengan melakukan penilaian. Penilaian merupakan suatu proses memberikan atau menentukan nilai kepada objek tertentu berdasarkan suatu kriteria (Sudjana, 2013). Penilaian dilakukan oleh guru untuk memantau proses, kemajuan, dan perbaikan hasil belajar peserta didik secara berkesinambungan. Menurut pendapat Nuriyah (2014) suatu penilaian tidak bisa terlepas dari kegiatan pembelajaran. Jika dalam kegatan pembelajaran terdapat siswa sebagai input, pembelajaran sendiri sebagai proses, dan hasil evaluasi pembelajaran sebagai hasil, kegiatan penilaian terjadi pada awal, proses, maupun diakhir pembelajaran. Penilaian ini dapat dilakukan salah satunya dengan menggunakan instrumen kognitif, yaitu dengan tes.

Penilaian kognitif sudah dilaksanakan sejak dulu untuk mengukur kompetensi terutama dalam ranah kognitif. Perbedaannya, pada kurikulum 2013 ini menggunakan penilaian autentik dimana penilaian pada aspek pengetahuan, sikap, dan juga keterampilan dilakukan secara berimbang. Sedangkan pada kurikulum sebelumnya yaitu KTSP penilaian kognitif yang lebih dominan dilaksanakan. Hal ini juga sesuai dengan pendapat Setiadi (2016) bahwa 
penilaian pada kurikulum 2013 dilakukan secara menyeluruh dibanding dengan penilaian yang ada pada Kurikulum 2006 atau kurikulum KTSP. Penilaian pada kurikulum 2013 dinamakan penilaian autentik, dimana guru diminta untuk melakukan penilaian pada ranah kognitif, afektif, dan juga psikomotor.

Saat ini, sistem pendidikan di Indonesia telah mengalami beberapa kali perubahan, yang terbaru yaitu Kurikulum 2013. Perubahan dalam Kurikulum 2013 ini antara lain tentang pembelajaran dan penilaian hasil belajar. Penilaian hasil belajar merupakan salah satu hal yang penting dalam pendidikan karena penilaian merupakan akhir dari suatu proses pembelajaran. Karena itu, pelaksanaan penilaian yang dilakukan oleh guru harus sesuai dengan standar penilaian yang telah ditetapkan. Standar penilaian pendidikan disusun sebagai acuan penilaian bagi guru, satuan pendidikan, dan pemerintah pada satuan pendidikan untuk jenjang pendidikan dasar dan menengah yang ditetapkan.

Penerapan kurikulum 2013 saat ini masih ada titik kelemahan yang perlu diperhatikan. Salah satunya sosialisasi Kurikulum 2013 yang belum merata ke seluruh guru sehingga masih banyak guru yang belum memahami dengan baik bagaimana cara mengimplementasikan Kurikulum 2013 sehingga hasilnya masih sangat diragukan (Nurmawati, 2014). Meskipun kurikulum 2013 telah diterapkan hampir disemua sekolah, namun dalam pelaksanaannya masih ditemukan kendala terutama dalam sistem penilaian (Kastina, 2017). Kurikulum 2013 ini menuntut kesiapan guru dengan kecakapan dalam melakukan penilaian hasil belajar sesuai dengan standar penilaian pendidikan yang terbaru.

Kriteria sebuah tes sebagai alat penilaian yang baik adalah terpenuhinya syarat validitas, reliabilitas, objektivitas, praktibilitas, dan ekonomis. Penulisan butir soal yang baik dalam instrumen tes sangat diperlukan, karena hanya dengan alat ukur yang baik maka akan didapatkan hasil evaluasi belajar yang tepat. Karena itu, dalam penyusunan sebuah instrumen tes, guru haruslah memperhatikan prosedur yang telah ditetapkan.

Pedoman penyusunan instrumen ini memuat komponen-komponen yang perlu diperhatikan dalam pengembangan soal uji tulis yang baik, meliputi penulisan kisi-kisi soal, penulisan butir soal, penelaahan butir soal dan pemeriksaan hasil tes. Menurut Mardapi (2017) terdapat sembilan langkah dalam mengembangkan tes, yaitu menyusun spesifikasi tes, menulis tes, menelaah tes, melakukan uji coba tes, menganalisis butir tes, memperbaiki tes, merakit tes, melaksanakan tes, dan menafsirkan hasil tes. Namun, berdasarkan hasil wawancara yang telah dilakukan kepada guru IPA (Biologi) di SMP N 1, 2, dan 3 Bantul, masih ada guru yang belum melakukan telaah soal dan uji coba soal. Hal tersebut karena 
keterbatasan waktu yang dimiliki oleh guru dengan tuntutan yang harus dikerjakan sebagai seorang guru.

Pemahaman guru terhadap prosedur penyusunan instrumen juga kurang. Terbatasnya pemahaman guru tersebut karena kurangnya sosialisasi dan pelatihan dalam pembuatan instrumen tes. Apabila ada sosialisasi dan pelatihan pun hanya perwakilan guru saja yang menghadiri, kemudian informasi yang diperoleh dari guru yang menghadiri pelatihan tersebut diberikan kepada guru yang lain. Sehingga adanya keterbatasan informasi yang diterima.

Berdasarkan hasil wawancara dengan beberapa guru IPA (Biologi) di masing-masing sekolah, soal Penilaian Tengah Semester (PTS) maupun soal Penilaian Akhir Semester (PAS) tidak disusun sendiri oleh guru melainkan disusun oleh tim Musyawarah Guru Mata Pelajaran (MGMP). Guru hanya sebatas membuat soal saja kemudian dikumpulkan ke tim MGMP. Tim MGMP yang kemudian akan menyusun dan memilah soal tersebut mana yang layak untuk digunakan dan mana yang tidak. Kemudian dari tim MGMP diberikan lagi kepada guru di masing-masing sekolah untuk diujikan. Untuk analisis soal, guru juga tidak melakukan karena soal maupun jawaban dari peserta didik tidak dikembalikan ke sekolah, sehingga guru hanya menerima hasil saja.

Sekolah Menengah Pertama (SMP) Negeri Sekecamatan Bantul sudah terakreditasi A. Berdasarkan nilai rata-rata Ujian Nasional (UN) tahun 2018, dari 58 Sekolah Menengah Pertama (SMP) Negeri se Kabupaten Bantul, SMP Negeri 1 Bantul berada pada peringkat 3 se Kabupaten Bantul dengan nilai rata-rata 83,58. SMP Negeri 2 Bantul berada pada peringkat 1 dengan nilai rata-rata 86,41, dan SMP Negeri 3 Bantul berada pada peringkat 14 dengan nilai rata-rata 71,20.

Berdasarkan latar belakang masalah tersebut, dilakukan penelitian yang berjudul "Evaluasi Proses Penyusunan Instrumen Penilaian Kognitif pada Mata Pelajaran IPA (Biologi) di SMP Negeri Sekecamatan Bantul”. Melalui penelitian ini diharapkan dalam penyusunan soal-soal tes sebagai alat penilaian untuk lebih memperhatikan prosedur penyusunan yang telah ditetapkan sesuai dengan standar penilaian pendidikan sehingga dapat digunakan untuk mengukur tingkat keberhasilan peserta didik dalam pembelajaran secara baik.

\section{METODE}

Penelitian ini merupakan penelitian evaluasi. Penelitian dilaksanakan di SMP Negeri sekecamatan Bantul. Adapun populasi yang digunakan dalam penelitian ini yaitu seluruh 
guru mata pelajaran IPA di SMP Negeri 1 Bantul, SMP Negeri 2 Bantul, dan SMP Negeri 3 Bantul yaitu sebanyak 16 responden. Jumlah sampel ditentukan berdasarkan teknik sampel jenuh sehingga seluruh anggota populasi dijadikan sebagai sampel. Teknik pengumpulan data menggunakan kuesioner dan wawancara. Instrumen disajikan dalam bentuk lembar kuesioner yang mencakup latar belakang guru, pengalaman sosialisasi dan pelatihan, serta langkah pengembangan tes yang dilakukan guru, dan pedoman wawancara. Data yang diperoleh berasal dari jawaban guru dalam mengisi lembar kuesioner dan hasil wawancara dengan guru berkaitan dengan bagaimana langkah pengembangan tes yang dilakukan oleh guru tersebut. Data yang telah diperoleh kemudian dianalisis menggunakan analisis deskriptif kuantitatif. Hasil analisis data selanjutnya digunakan sebagai dasar pertimbangan apakah sesuai atau tidak langkah pengembangan tes yang dilakukan oleh guru dengan prosedur pengembangan tes yang telah ditetapkan.

\section{HASIL DAN PEMBAHASAN}

Data penelitian diperoleh dengan menggunakan kuesioner yang diberikan kepada guru mata pelajaran IPA untuk mengukur sejauh mana guru dapat melakukan langkah-langkah pengembangan tes sesuai dengan prosedur penyusunan instrumen tes. Hasil analisis data pada penelitian ini meliputi: latar belakang pendidikan guru, pengalaman sosialisasi dan pelatatihan pembuatan instrumen tes, dan kemampuan guru dalam mengembangkan instrumen tes.

\section{Latar Belakang Pendidikan Guru}

Guru pada SMP/MTs, atau bentuk lain yang sederajat, harus memiliki kualifikasi akademik pendidikan minimum diploma empat (D-IV) atau Sarjana (S1) program studi yang sesuai dengan mata pelajaran yang diajarkan/diampu, dan diperoleh dari program studi yang terakreditasi (Permendiknas, 2007). 


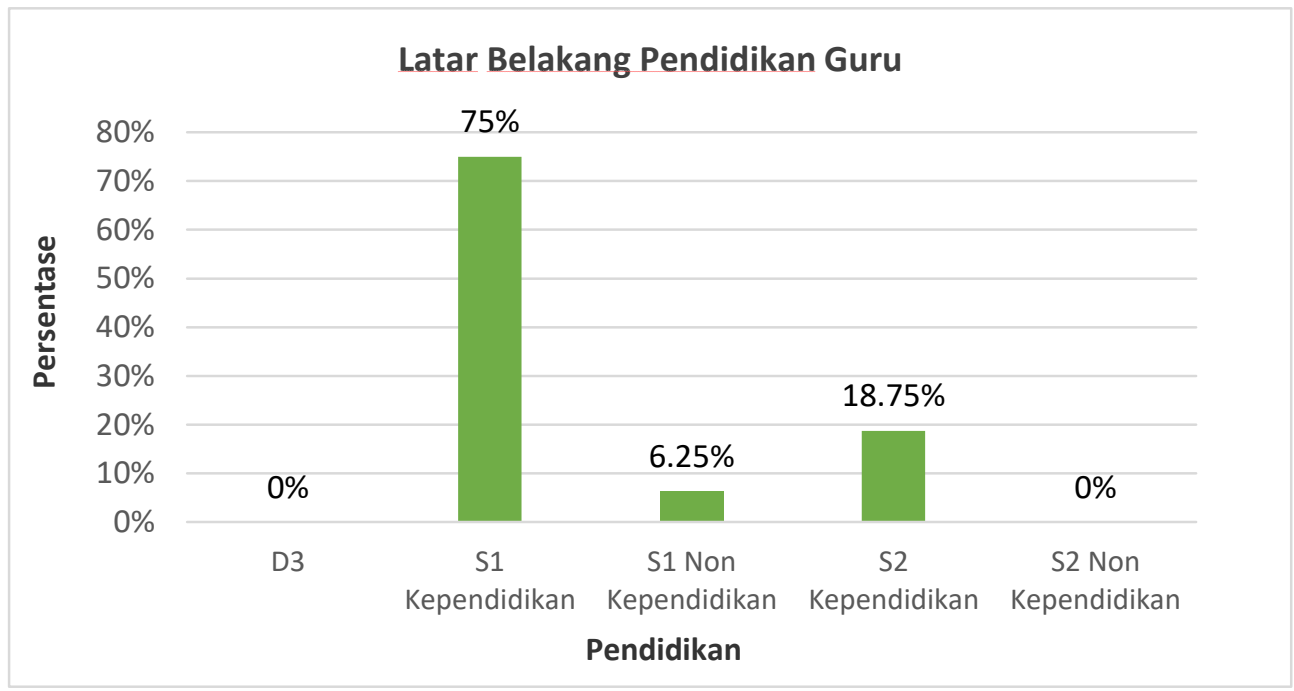

Gambar 1. Latar Belakang Pendidikan Guru

Berdasarkan gambar diatas, dapat dilihat bahwa sebagian besar responden memiliki latar belakang pendidikan yaitu Strata 1 (S1) sebanyak 75\%. Hal ini sesuai dengan syarat kualifikasi akademik yang harus dimiliki oleh seorang pendidik yaitu diploma empat (D-IV) atau Sarjana (S1). Latar belakang pendidikan guru ini penting dan harus sesuai dengan jurusanya karena dengan begitu guru dapat membelajarkan sesuai dengan keilmuan yang telah diperolehnya secara profesional.

Guru dengan latar belakang dari kependidikan atau dari institusi Lembaga Pendidikan Tenaga Kependidikan (LPTK) dan guru dengan latar belakang dari non kependidikan atau dari institusi non LPTK juga memiliki perbedaan. Institusi LPTK ini akan menghasilkan output yaitu sebagai guru, sedangkan institusi non LPTK menghasilkan output sebagai sarjana ilmu murni. Berdasarkan hasil kuesioner yang diisi oleh salah satu responden yang memiliki latar belakang dari non kependidikan atau non LPTK, ternyata dalam memberikan jawabannya responden tersebut kurang paham.

Karena itu, guru harus memiliki penguasaan pada bidang keilmuan tertentu. Kesesuaian antara ilmu yang dimiliki guru dengan mata pelajaran yang diampu juga sangat penting. Hal ini senada dengan penelitian Damayanthi (2014) bahwa mahasiswa kependidikan atau dari institusi LPTK telah diberi penekanan materi pada ilmu pendidikan di luar ilmu murni yang sesuai dengan jurusannya sehingga telah dipersiapkan untuk menjadi pendidik. Sedangkan mahasiswa dari non kependidikan atau dari institusi non LPTK mahasiswa tidak memperoleh materi kependidikan melainkan hanya ilmu murni yang sesuai dengan jurusannya. 


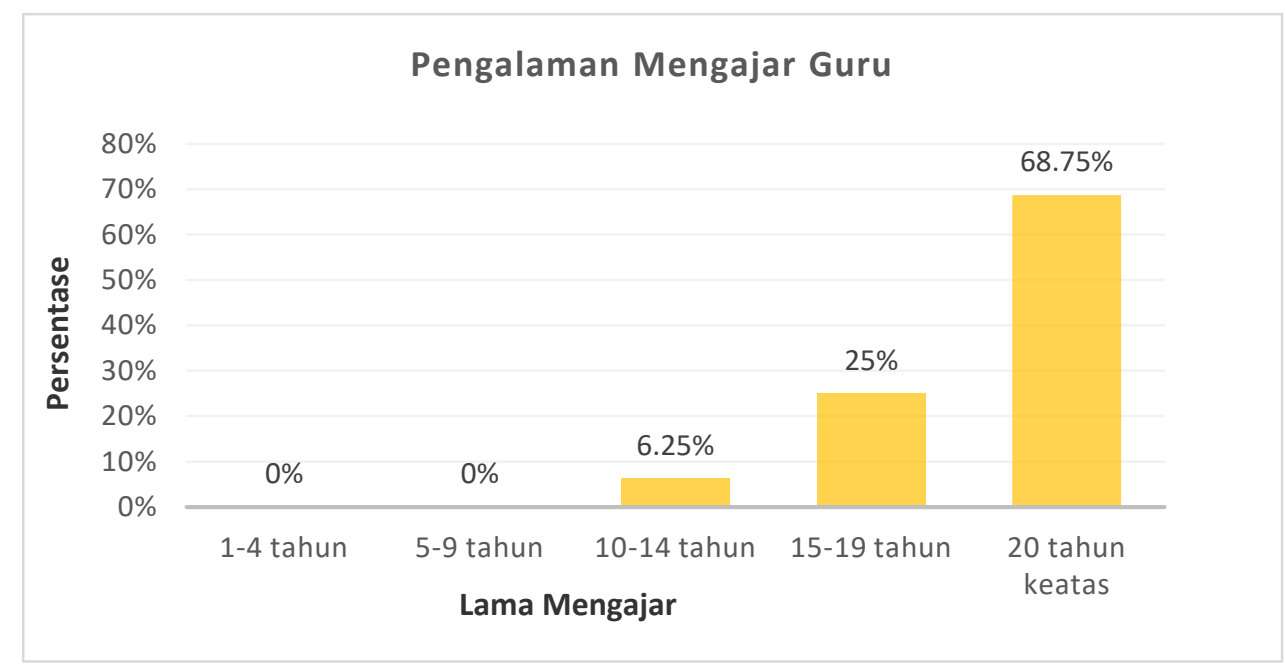

Gambar 2. Pengalaman Mengajar Guru

Berdasarkan pada gambar 2, dapat dilihat bahwa sebagian besar guru yaitu sebayak 68,75\% memiliki pengalaman mengajar selama lebih dari 20 tahun. Latar belakang pengalaman mengajar ini dapat menjadi acuan apakah dalam jangka waktu tersebut responden mampu membuat soal yang baik sesuai dengan kaidah penyusunan soal. Pengalaman mengajar ini juga berpengaruh pada profesionalisme guru. Jadi, semakin lama pengalaman mengajar guru akan semakin tinggi profesionalitasnya.

Proses penyusunan instrumen tes ini termasuk ke dalam kompetensi pedagogik guru. Sesuai dengan Permendiknas Nomor 16 Tahun 2007 bahwa "mengembangkan instrumen penilaian dan evaluasi proses dan hasil belajar termasuk kedalam kompetensi pedagogik guru." Berdasarkan hasil penelitian yang dilakukan, waktu mengajar responden memiliki rata-rata lebih dari 20 tahun. Dengan waktu selama itu, ternyata responden belum mampu membuat soal sesuai dengan kaidah pembuatan soal. Seharusnya tingkat pendidikan dan pengalaman mengajar guru dapat berpengaruh positif terhadap kompetensi pedagogik guru (Awan, 2019: 48). Namun pada kenyataannya, hal tersebut belum membuat guru paham terhadap kaidah dalam penyusunan instrumen tes.

\section{Sosialisasi dan Pelatihan}

Kegiatan sosialisasi penting dilakukan karena sosialisasi kurikulum, dalam penelitian ini khususnya pada aspek penilaian pada hakikatnya merupakan proses pembelajaran kepada tenaga pengajar untuk mempelajari aspek penilaian yang akan diterapkan sesuai dengan konsep pengembangan kurikulum dan diharapkan dalam implementasinya dapat dilaksanakan sesuai dengan tujuan yang telah ditentukan (Fussalam, 2018: 50). 


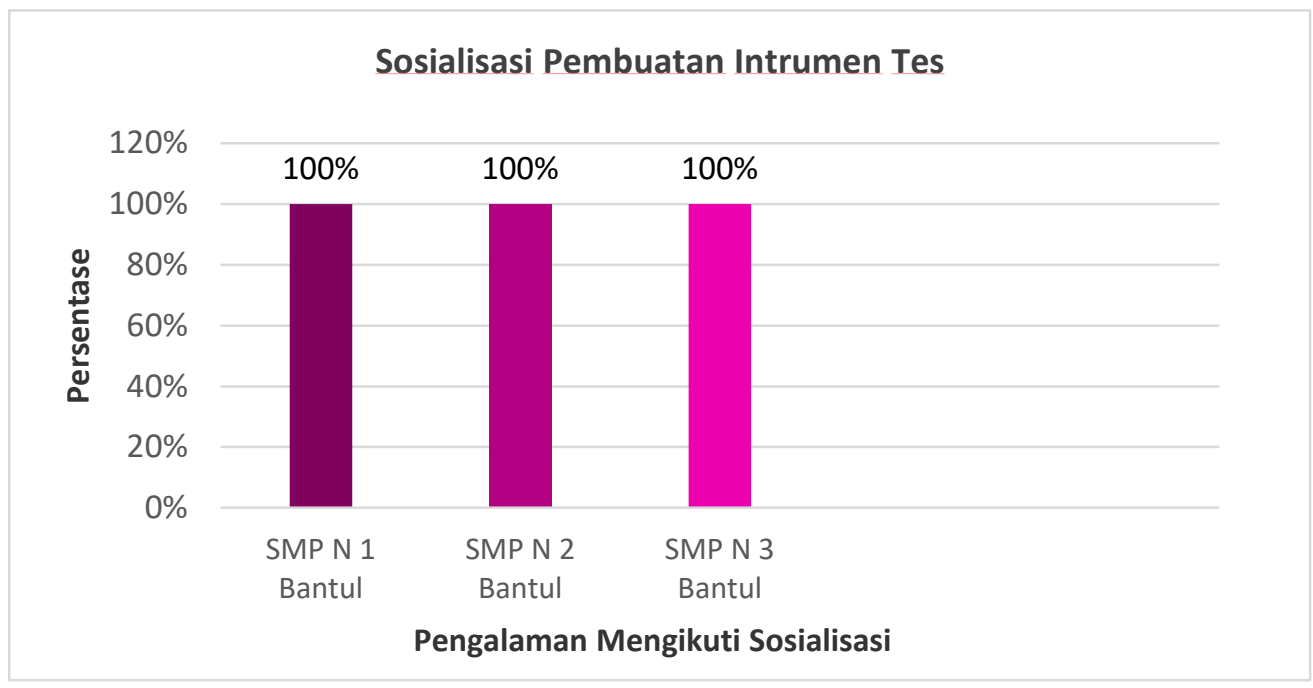

Gambar 3. Pengalaman dalam Mengikuti Sosialisasi

Berdasarkan gambar 3 menunjukkan bahwa 100\% responden pernah mendapatkan sosialisasi mengenai pembuatan instrumen tes. Sosialisasi tersebut baik yang diselenggarakan dari pihak Dinas Pendidikan Kabupaten, Lembaga Penjaminan Mutu Pendidikan (LPMP), Kepala Sekolah, maupun Pengawas Sekolah. Adanya sosialisasi ini penting dilakukan karena sosialisasi menjadi kunci utama dalam memahami kurikulum 2013.

Namun pada kenyataannya sosialisasi yang didapat oleh responden ternyata belum mampu menambah wawasan responden terkait langkah penyusunan instrumen tes, dibuktikan dengan hasil responden dalam mengisi kuesioner. Hal ini disebabkan kurangnya sosialisasi dan banyaknya tanggung jawab yang harus dikerjakan oleh seorang guru dengan keterbatasan waktu yang ada karena setiap kali ada sosialisasi hanya perwakilan saja yang ditunjuk untuk mewakili tiap sekolah sehingga adanya keterbatasan informasi yang diterima oleh guru. Jadi, adanya sosialisasi yang telah diadakan ini kurang maksimal. 


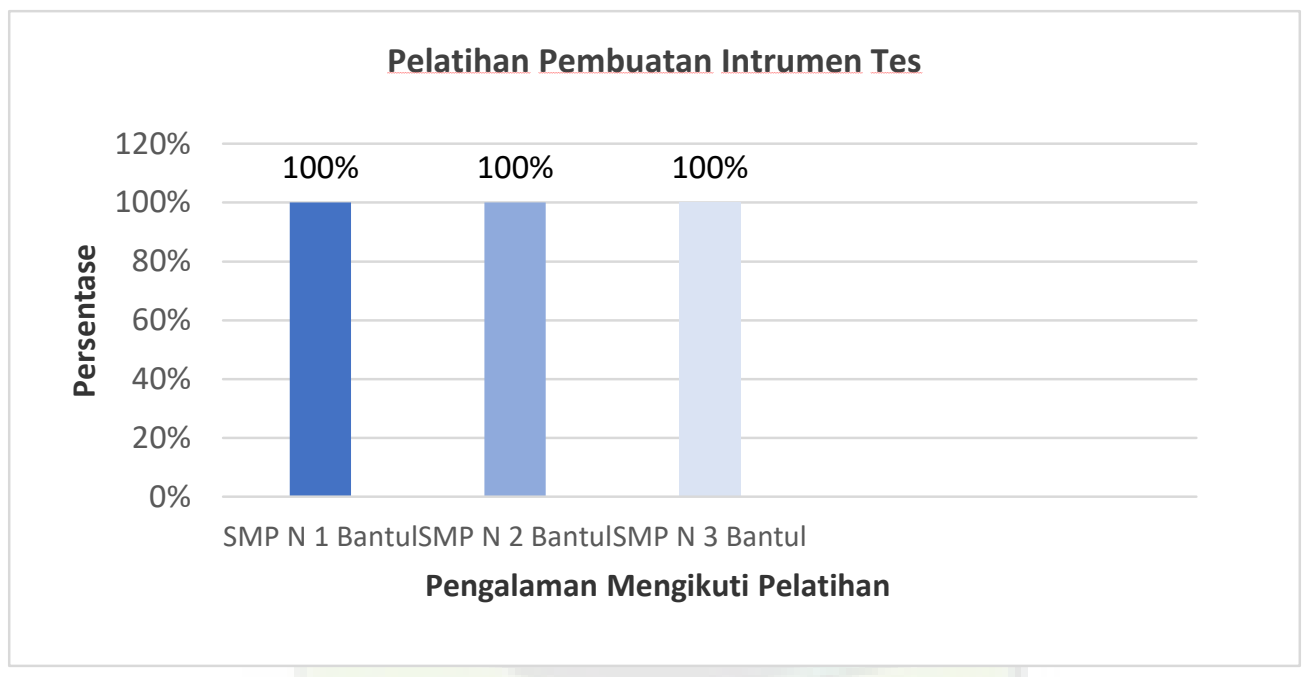

Gambar 4. Pengalaman dalam Mengikuti Pelatihan

Gambar 4 menunjukkan pengalaman guru dalam mengikuti pelatihan penyusunan instrumen tes. Berdasarkan gambar 4, 100\% responden pernah mengikuti pelatihan yang diadakan baik dari Dinas Pendidikan Kabupaten, Lembaga Penjaminan Mutu Pendidikan (LPMP), Sekolah, maupun dari Musyawarah Guru Mata Pelajaran (MGMP) tingkat Kabupaten.

Kegiatan pelatihan penting dilakukan karena untuk meningkatkan pengetahuan, keterampilan dan perilaku yang ditekankan pada program pelatihan serta dapat diaplikasikan dalam kegiatan sehari-hari (Kurniawan, 2017: 183). Namun, pada kenyataannya pelatihan yang didapat ternyata belum mampu menambah pengetahuan dan kemampuan responden dalam membuat instrumen tes. Hal ini disebabkan karena kurangnya sosialisasi dan pelatihan. Meskipun semua responden saat menjawab kuesioner pernah mengikuti pelatihan, namun saat dilakukan wawancara ada yang mengatakan bahwa jika ada pelatihan hanya perwakilan guru saja yang diminta untuk menghadiri pelatihan yang diselenggarakan.

Jadi, guru belum mencapai tujuan diselenggarakannya pelatihan, yaitu untuk; (1) meningkatkan self awarness, (2) meningkatkan keterampilan dan keahlian yang dimiliki, serta (3) meningkatkan motivasi dan profesionalitas kerja (Kurniawan, 2017: 184).

\section{Kemampuan dalam Mengembangkan Instrumen Tes}

Terdapat sembilan langkah dalam penyusunan intrumen tes, mulai dari tahap penyusunan spesifikasi tes, menulis tes, menelaah tes, melakukan uji coba tes, menganalisis butir tes, memperbaiki tes, merakit tes, melaksanakan tes, dan menafsirkan hasil tes (Mardapi, 2017: 95). Agar dihasilkan soal yang baik, maka seorang guru dalam membuat soal haruslah memperhatikan tahap penyusunan instrumen tes tersebut. 


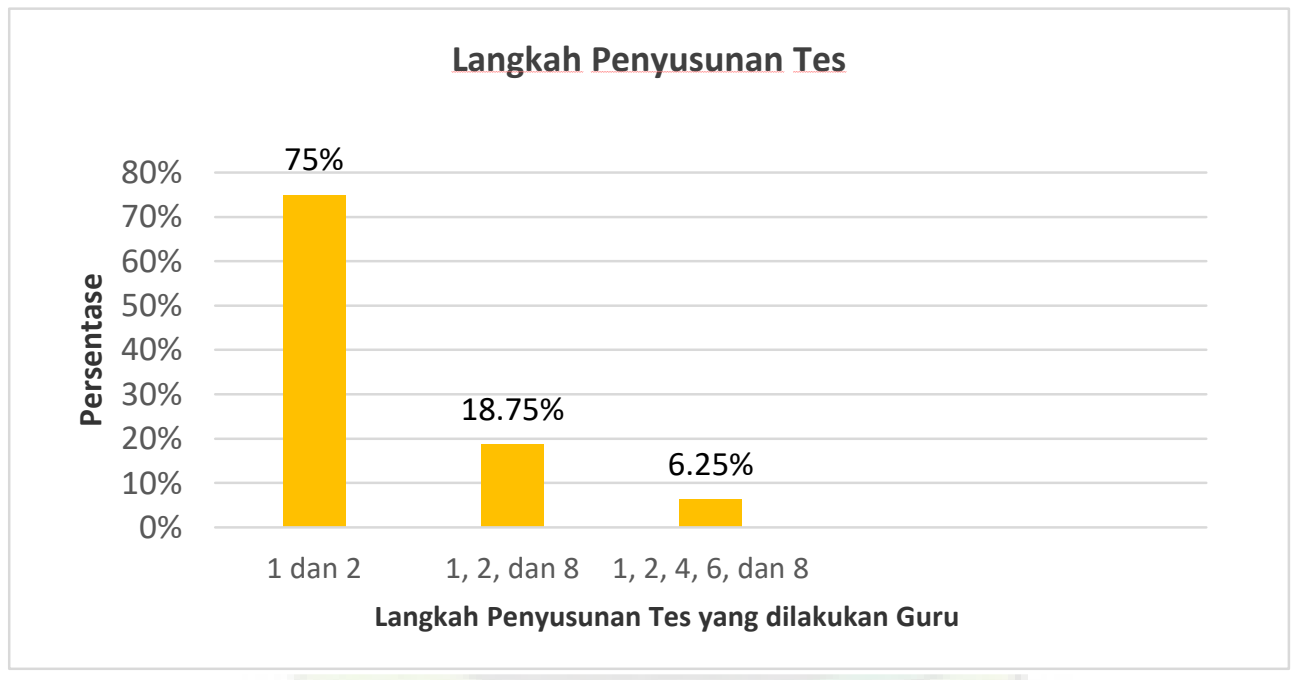

Gambar 5. Langkah Pengembangan Tes yang Dilakukan Guru

Berdasarkan gambar 5, dapat dilihat bahwa dalam mengembangkan instrumen tes, tidak ada responden yang melakukan semua langkah sesuai dengan prosedur yang ada. Guru tidak menyusun sendiri instrumen tes yang digunakan untuk Penilaian Tengah Semester (PTS) maupun Penilaian Akhir Semester (PAS) melainkan disusun oleh tim MGMP. Sedangkan untuk Ulangan Harian, soal disusun sendiri oleh guru mata pelajaran masing-masing.

Meskipun guru tidak menyusun sendiri instrumen tes untuk Penilaian Tengah Semester (PTS) dan Penilaian Akhir Semester (PAS), tetapi guru tetap membuat soal yang kemudian dikumpulkan kepada tim MGMP. Tim MGMP kemudian yang akan memilah mana soal yang layak dan tidak layak untuk diujikan. Dalam pembuatan soal ini guru juga belum melakukan langkah-langkah pengembangan tes sesuai dengan prosedur, tetapi hanya membuat soal saja belum melalui tahap analisis soal maupun uji coba tes, karena soal dan lembar jawab siswa dikembalikan lagi kepada tim MGMP.

Pertimbangan guru menggunakan soal Penilaian Tengah Semester (PTS) dan Penilaian Akhir Semester (PAS) dari MGMP yaitu berdasarkan kebijakan dari sekolah hasil musyawarah dengan kepala sekolah dan juga menyesuaikan dengan kondisi dan kebutuhan sekolah. Selain itu juga karena keterbatasan waktu yang ada. Hal ini juga didukung dengan penelitian yang dilakukan oleh Awan (2019: 45) bahwa banyaknya teknik penilaian menuntut guru untuk dapat membuat rencana instrumen dan rubrik penilaian yang sangat banyak. Sedangkan di lapangan, guru banyak mengalami kesulitan dalam membagi waktu untuk melaksanakan penilaian dan menyampaikan materi.

Jadi, meskipun responden telah memperoleh sosialisasi maupun pelatihan tentang pembuatan instrumen tes, mereka kurang paham mengenai langkah pengembangan tes karena 
selama mengikuti pelatihan peserta hanya mendengarkan ceramah saja. Ditambah lagi tidak dipraktekkan secara langsung dalam membuat soal melainkan menggunakan intrumen tes yang telah dibuat oleh lembaga terkait.

Sesuai dengan penelitian yang dilakukan oleh Ahmad (2014: 102) bahwa pelatihan belum dapat merubah mindset guru, karena selama pelatihan guru hanya mendengarkan tutor ceramah saja, tidak ditekankan dengan pendekatan scientific yaitu dengan mengamati, bertanya, dan mencoba. Untuk bisa merubah mindset guru ini tidak mudah dan membutuhkan waktu yang lama untuk belajar dan membiasakan diri.

Berdasarkan gambar 5, dari sembilan tahap dalam penyusunan instrumen tes sebanyak $75 \%$ responden hanya melakukan dua tahap saja yaitu menyusun spesifikasi tes dan menulis tes. Dapat dikatakan responden membuat soal hanya dengan pemahamannya sendiri, tidak memperhatikan prosedur dalam menyusun instrumen tes. Walaupun responden sudah pernah mendapatkan sosialisasi dan mengikuti pelatihan penyusunan interumen tes, responden tetap menggunakan langkah/caranya sendiri dalam membuat soal. Hal ini karena keterbatasan waktu.

Selain itu, responden juga hanya menggunakan soal yang dibuat oleh lembaga seperti MGMP. Jadi responden kurang begitu paham akan pembuatan soal yang sesuai dengan kaidah karena tidak diimbangi dengan mempraktikkan secara langsung. Jadi adanya sosialisasi maupun pelatihan yang telah diikuti oleh guru pada kenyataanya belum berjalan maksimal, karena belum bisa menambah pengetahuan guru tentang bagaimana prosedur pengembangan tes yang benar sesuai dengan prosedur yang telah ditetapkan.

\section{SIMPULAN}

Berdasarkan analisis data yang telah dipaparkan, didapatkan kesimpulan sebagai berikut. 1) Semua guru IPA di SMP Negeri Sekecamatan Bantul dalam mengembangkan instrumen tes belum melakukan langkah-langkah pengembangan tes sesuai dengan prosedur yang ada. 2) Langkah pengembangan instrumen tes yang dilakukan oleh guru di SMP Negeri Sekecamatan Bantul belum sesuai dengan prosedur penyusunan instrumen tes. Dari sembilan langkah dalam penyusunan instrumen tes sebanyak $75 \%$ guru hanya mengikuti langkah sampai pada langkah ke dua saja yaitu menulis tes, sebanyak $18,75 \%$ guru hanya melakukan langkah penyusunan spesifikasi tes, menulis tes, dan melaksanakan tes, dan sebanyak $6,25 \%$ guru melakukan langkah penyusunan spesifikasi tes, menulis tes, uji coba tes, perbaikan tes, dan melaksanakan tes. 


\section{REFERENSI}

Ahmad, Syarwan. 2014. "Problematika Kurikulum 2013 dan Kepemimpinan Instruksional Kepala Sekolah". Jurnal Pencerahan. 8(2). 98-108.

Awan, Meiseti, Hartono, dan S.E.N. 2019. "Keterlaksanaan Penilaian Autentik Dilihat dari Pengalaman Mengajar dan Kualifikasi Pendidik". Unnes Physics Education Journal. 8(1). 44-50.

Damayanthi, Ayu Eka, dkk. 2014. "Analisis Kompetensi Pedagogik dan Kompetensi Profesional Ditinjau dari Output Institusi pada Para Guru SMP Negeri di Kota Denpasar”. Jurnal Administrasi Pendidikan Indonesia. 5(1).

Depdiknas. 2007. Peraturan Menteri Pendidikan Nasional Republik Indonesia Nomor 16 Tahun 2007 Tentang Standar Kualifikasi Akademik dan Kompetensi Guru. Jakarta: Depdiknas.

Fussalam, Yahfenel Evi, dan Elmiati. 2018. "Implementasi Kurikulum 2013 (K13) SMP Negeri 2 Sarolangun 1". Jurnal Muara Pendidikan. 3(1). 45-55.

Kastina, Zulian Vina. 2017. "Implementasi Sistem Penilaian dalam Kurikulum 2013 di SMA Negeri 2 Pekanbaru". Jurnal Online Mahasiswa FISIP. 4(1). 1-15.

Kurniawan, Riza Yonisa, et al. 2017. "Pemberian Pelatihan Analisis Butir Soal Bagi Guru di Kabupaten Jombang”. Jurnal Pemberdayaan Masyarakat Madani (JPMM). 1(2). 179193.

Mardapi, Djemari. 2017. Pengukuran, Penilaian, dan Evaluasi Pendidikan. Yogyakarta: Parama Publishing.

Nuriyah, Nunung. 2014. "Evaluasi Pembelajaran: Sebuah Kajian Teori”. Jurnal Pendidikan Sosial \& Ekonomi. 3(1).

Nurmawati, Sri Dewi, et al. 2014. "Studi Evaluasi Kesiapan Guru dalam Melaksanakan Kurikulum 2013 di Madrasah Aliyah Negeri Amlapura Tahun 2014". Jurnal Administrasi Pendidikan Indonesia. 5(1).

Setiadi, Hari. 2016. "Pelaksanaan Penilaian pada Kurikulum 2013". Jurnal Penelitian dan Evaluasi Pendidikan. 20(2).

Sudjana, Nana. 2013. Penilaian Hasil Proses Belajar Mengajar. Bandung: PT Remaja Rosdakarya. 